\title{
Peningkatan Efisiensi Energi pada Kendaraan Listrik dengan Elektronik Diferensial Berbasis ANN (Artificial Neural Network)
}

\author{
SOFYAN AHMADI ${ }^{1}$, KHAIRUL ANAM ${ }^{2}$, WIDJONARKO3 \\ 1Magister Teknik Elektro Universitas Jember, Indonesia \\ 2,3Teknik Elektro Universitas Jember, Indonesia \\ Email : sofyan.ahmadi1993@gmail.com
}

Received 6 April 2020 | Revised 3 Mei 2020 | Accepted 12 Mei 2020

\begin{abstract}
ABSTRAK
Seiring dengan perkembangan teknologi kendaraan listrik yang saat ini semakin canggih dan berkembang sangat cepat, upaya pengembangan kendaraan listrik terus dilakukan, salah satunya penggunaan motor BLDC dalam kendaraan listrik untuk meningkatkan efisiensi. Penelitian ini menggunakan kontrol ANN (Artificial Neural Network) pada mikrokontroler serta metode differential untuk pengontrolan kecepatan putar motor BLDC. Pengujian Percepatan dengan menempuh jarak 200 meter arus rata-rata sebesar 1,05 ampere. Daya rata-rata pada pengujian efisiensi sebesar 101 watt. Hasil efisiensi dari pengujian dengan panjang lintasan sejauh 3,3 km dengan waktu tempuh 10 menit didapatkan hasil efisiensi energi dari sistem kendaraan sebesar 179,34 km/kwh.
\end{abstract}

Kata kunci: Motor BLDC, Elektronik Diferensial, Neural network-Logic, Akselerasi, Efisiensi.

\begin{abstract}
Along with the development of electric vehicle technology that is currently increasingly sophisticated and growing very fast. efforts to develop electric vehicles continue to be done, one of them the use of BLDC motor in electric vehicles to improve efficiency. In this study using ANN (Artificial Neural Network) control on the microcontroller as well as the differential method for controlling the rotational speed of the BLDC motor. Acceleration Testing with a distance of 200 meters average flow of 1.05 amperes. The average power on the 101 watt efficiency test. The efficiency of the test with the length of the track as far as 3.3 $\mathrm{km}$ with the travel time of 10 minutes obtained the efficiency of energy in the vehicle system of $179.34 \mathrm{~km} / \mathrm{kwh}$.
\end{abstract}

Keywords: BLDC Motor, Electronic Differential, Neural network-Logic, Acceleration, Efficiency. 
Peningkatan Efisiensi Energi Pada Kendaraan Listrik dengan Elektronik Diferensial Berbasis ANN

(Artificial Neural Network)

\section{PENDAHULUAN}

Penggunaan motor listrik pada dunia otomotif di era sekarang berkembang dengan pesat. Penggunaan motor listrik salah satunya dapat diaplikasikan pada mobil listrik. Pada dasarnya sistem kerja motor listrik adalah mengkonversi energi listrik menjadi energi gerak. Mobil listrik mempunyai kelebihan dari pada mobil konvesional yang menggunakan motor bakar, yakni lebih ramah lingkungan karena tidak menghasilkan gas sisa pembakaran yang dapat mencemari lingkungan serta tidak menimbulkan bising (Dehong, dkk, 2017).

Dalam kendaraan listrik motor BLDC banyak digunakan sebagai penggerak utama karena mudah dalam penerapanya karena mempunyai torsi yang besar sehingga memiliki arus medan yang lebih besar dari motor DC. Motor BLDC mempunyai kekurangan karena membutuhkan komutator mekanik atau sikat dalam pengoperasiannya sehingga perlu dilakukan pemeliharaan yang rutin atau melakukan pergantian komutator mekanik (sikat) secara berkala. Karena motor DC mempunyai kelemahan dalam hal perawatan maka dalam mobil listrik dipakai motor BLDC untuk penggerak utama karena tidak adanya komutator mekanik sehingga lebih mudah dalam penerapannya pada kendaraan listrik. Untuk efisiensi motor BLDC lebih tinggi dari motor DC karena rotor terbuat dari magnet permanen (Setiawan, dkk, 2019).

Dalam pengoprasian motor BLDC pada bagian rotor diperlukan sumber tegangan tiga fasa. Karena pada motor BLDC sumber tegangan adalah arus searah atau tegangan DC maka diperlukan suatu inverter tiga fasa untuk merubah tegangan DC menjadi Tegangan AC tida fasa. Dalam penggunaan inverter terdapat dua metode yaitu metode six-step metode PWM sinusoidal. Namun dalam penerapan pengendalian motor BLDC banyak digunakan metode six-step karena mempunyai algoritma yang sederhana serta mempunyai kesetabilan yang tinggi. Untuk meningkatkan kehandalan dalam metode six-step diperlukan pengaturan frekuensi yang sesuai. Kemudian Untuk meningkatkan efisiensi yang lebih pada motor BLDC dibutuhkan suatu sistem kontrol siklus tertutup (Prasetyo, dkk, 2017) (Al-Fiky, dkk, 2019). Terdapat beberapa macam metode algoritma dalam desain kontrol siklus tertutup ini , salah satunya adalah kontrol neural network

Untuk meningkatkan efisiensi energi dalam menjalankan kendaraan listrik diperlukan suatu kontrol dalam hal sistem kemudi. Sistem kemudi yang diharapkan berupa kontrol elektronik yang biasa di sebut elektronik diferensial kontrol motor. Dalam diferensial kontrol akan dilakukan perubahan kecepatan antara motor kanan dan kiri pada kendaraan listrik sehingga diharapkan slip atau gesekan dengan jalan pada saat kendaraan berjalan dapat diminimalkan (Kivanc \& Ustun 2019) (Daya, dkk, 2016) (Gago-Calderón, dkk, 2019) (Jigang, dkk, 2019).

Dalam penggunaan elektronik diferensial kontrol pada motor BLDC untuk kendaraan listrik diperlukan suatu kontrol siklus tertutup untuk mendapatkan efisiensi energi yang lebih. Dalam penelitian ini dipakai kontrol ANN (artificial Neural Network) karena mempunyai manfaat untuk menganalisa energi yang telah di dapatkan sehingga setelah dilakukan training atau pengolahan data didapatkan suatu persamaan untuk dimasukan ke dalam algoritma pengendalian motor BLDC. Dalam penerapannya kontrol ANN yang dipakai dapat memberikan pengontralan terhadap arus dan sudut kemudi untuk mendapatkan efisiensi energi yang maksimal. 


\section{METODE PENELITIAN}

\subsection{Sistem Pengontrolan Kemudi Elektronik Diferensial}

Dalam penelitian menggunakan metode pengontrolan dua motor BLDC dengan sistem diferensial. Sistem diferensial akan mengontrol putaran kedua motor BLDC sebagai sistem penggerak kendaraan listrik. Putaran motor yang selalu sama pada saat kendaraan berjalan akan rawan slip atau tergelincir, untuk itu dengan sistem pengontrolan elektronik diferensial motor BLDC akan memberikan putaran yang berbeda antara motor kanan dan motor kiri dengan mempertimbangkan sudut kemudi dan kenaikan arusnya. Pada Gambar 1 dapat dilihat sistem mekanik dalam kendaraan listik berbasis elektronik diferensial kontrol (GagoCalderón, dkk, 2019).

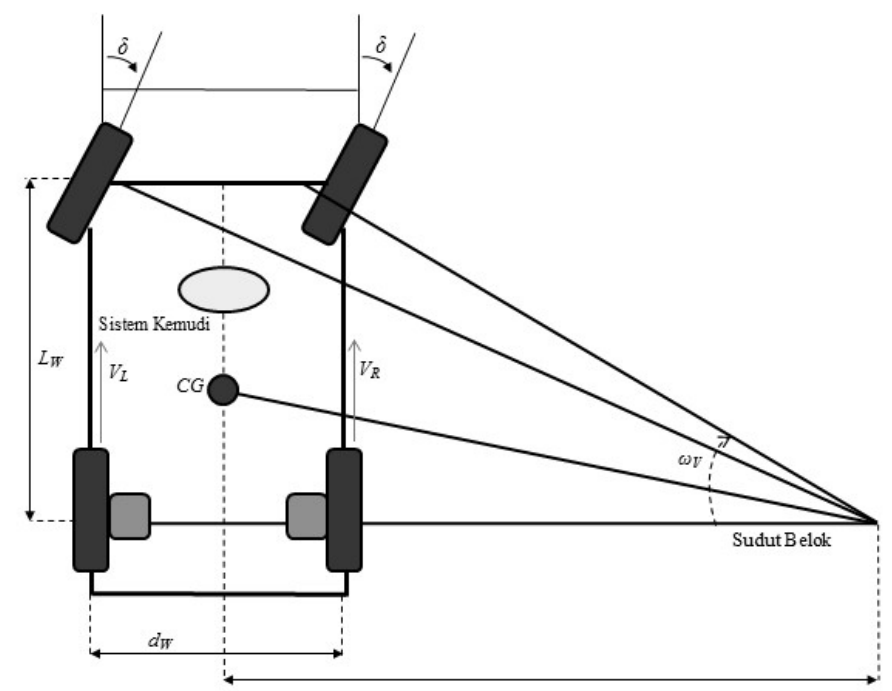

Gambar 1. Sistem Kemudi Diferensial Kendaraan Listrik

Untuk kendaraan yang dibuat mempunyai berat total $150 \mathrm{~kg}$ dengan berat pengemudi 60 $\mathrm{kg}$. Jadi beban total sistem kerja kontrol $210 \mathrm{~kg}$. Rangka yang dibuat dari bahan besi dengan posisi pengemudi terlentang dengan maksud untuk mendapatkan fungsi aerodinamis atau bebas hambatan udara. Penggunaan empat buah roda adalah untuk mendapatkan sistem kemudi yang lebih mudah serta daya pada motor yang dikeluarkan lebih rendah karena meminimalkan beban yang berat pada motor dan kontrol motor BLDC khususnya. Dalam sistem kemudi ini saat berbelok maka kecepatan antara motor BLDC kanan dan motor BLDC penggerak kiri akan berubah. Perubahan kecepatan putar pada motor penggerak BLDC ini untuk mendapatkan sistem kemudi yang baik atau menghindari dari slip saat kendaraan listrik dijalankan. Dengan memperkecil slip diharapkan efisiensi penggunaan energi listrik dapat ditingkatkan karena slip atau tergelincirnya roda pada sistem kemudi dapat meningkatkan arus sehingga efisiensi energi pada kendaraan listrik semakin rendah. 


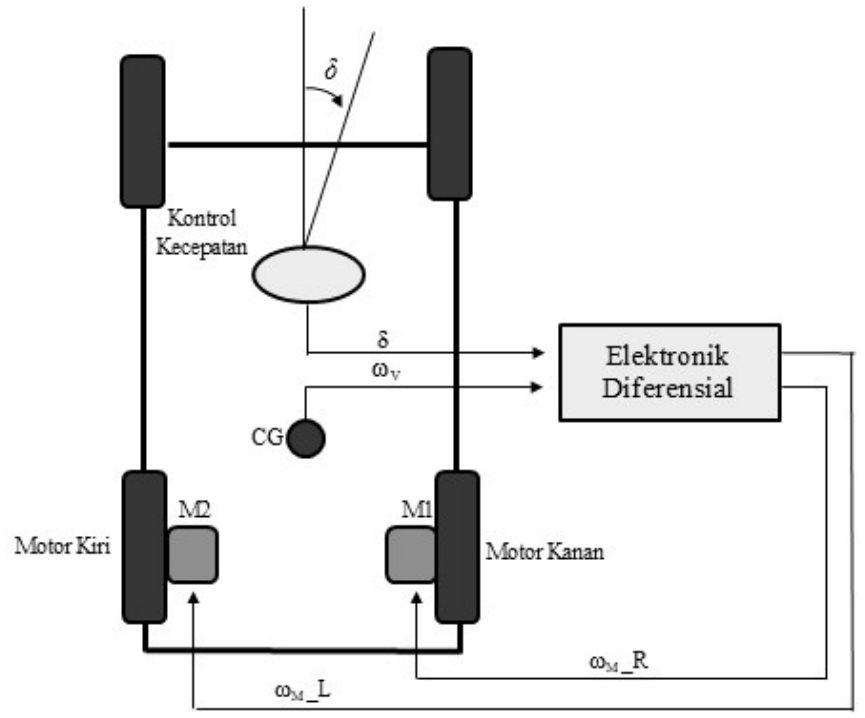

\section{Gambar 2. Sistem Elektronik Diferensial Pada Kendaraan Listrik}

Motor BLDC dipasang secara in-wheal atau jadi satu dengan roda sehingga tidak membutuhkan sistem transmisi mekanik. Penggunaan roda belakang dengan diameter sebsar 18 inchi sedangkan roda depan dengan diameter 15 inchi. Dalam perancangan ini diharapkan akan memberikan beban yang kecil sehingga penelitian pada kontrol motor BLDC menggunakan metode neural network-logic dapat berjalan dengan baik dengan beban yang tidak terlalu besar. Dalam sistem kemudi beban yang dipakai oleh kendaraan dapat dilihat pada persamaan satu dan dua. Pada Persamaan 1 adalah energi pada kendaraan listrik saat belok ke kiri dan Persamaan 2 energi pada saat kendaraan listrik belok ke kanan.

$$
\begin{aligned}
& \mathrm{W}_{\mathrm{L}}=\left(1+\left(\left(\tan ^{\delta}(\mathrm{pi} / 180) \mathrm{d}_{\mathrm{W}}\right) / \mathrm{Lw}_{\mathrm{W}}\right)\right)\left(\mathrm{V}_{\mathrm{L}} /(\mathrm{R})\right) \\
& \mathrm{W}_{\mathrm{R}}=\left(1+\left(\left(\tan ^{\delta}(\text { pi } / 180) \mathrm{d}_{\mathrm{W}}\right) / \mathrm{L}_{\mathrm{W}}\right)\right)\left(\mathrm{V}_{\mathrm{R}} /(\mathrm{R})\right)
\end{aligned}
$$

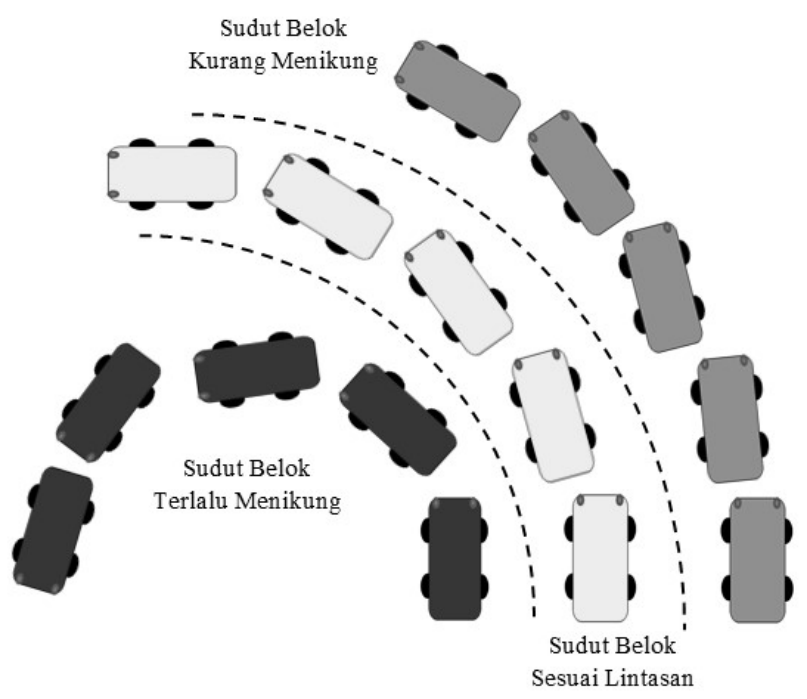

Gambar 3. Sistem Belok Kendaraan Listrik 
Pada Persamaan 1 dan Persamaan 2 dapat diketahui $W_{\mathrm{L}}$ adalah energi yang dibutuhkan kendaraan untuk belok ke kiri sedangkan $W_{R}$ adalah energi yang digunakan kendaraan untuk belok ke kanan. $d_{w}$ merupakan jarak antara motor penggerak kanan dan motor penggerak kiri. Untuk $L_{w}$ merupakan jarak antara roda depan dan roda belakang kendaraan. Kemudian untuk $V_{L}$ adalah kecepatan motor penggerak kiri dan $V_{R}$ adalah kecepatan penggerak motor sebelah kanan serta $\mathrm{R}$ merupakan diameter roda pada kendaraan yang digunakan.

\subsection{Rancangan Kendaran Listrik}

Dalam perancangan kendaraan listrik ini mempunyai bentuk sederhana dengan pengemudi sebanyak satu orang. Kendaraan terbuat dari besi dan serat viber. Desain mobil di pilih untuk mendapatkan bentuk sistem kemudi yang lebih mudah berbelok saat ditikungan.

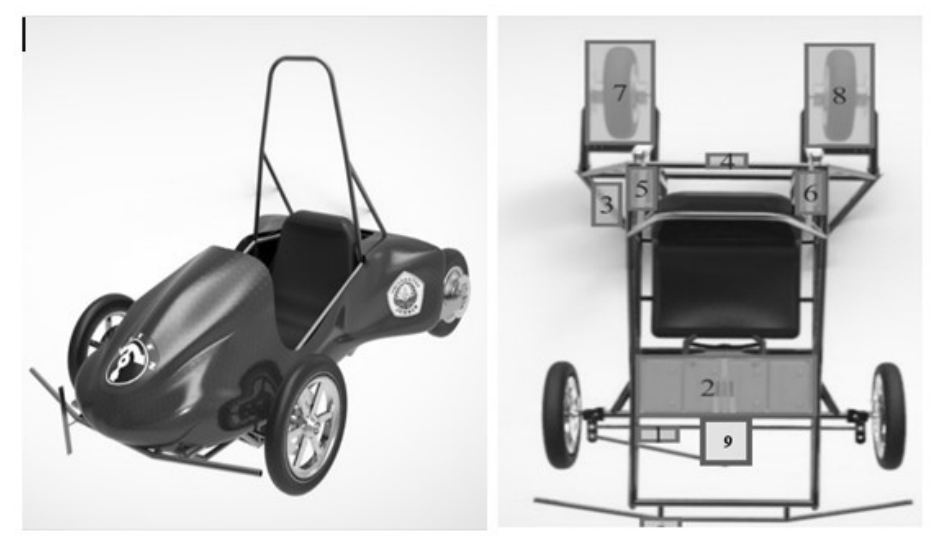

\section{Gambar 4. Bentuk Kendaraan Listrik dengan Elektronik Diferensial}

Motor BLDC yang dipakai dalam penelitian ini mempunyai daya sebesar 800 watt dengan model in-wheel yang menjadi kesatuan pada motor. Di dalam motor BLDC terdapat tiga buah sensor hall yang dipakai untuk menentukan proses komutasi yang akan diolah pada arduino slave. Dalam Gambar 3 diperlihatkan bentuk dari belokan yang baik pada kendaraan listrik. Sistem Kemudi yang baik akan memberikan keluaran arus atau arus yang digunakan lebih rendah karena tidak adanya slip atau resiko kendaraan listrik tergelincir. Dalam penelitian digunakan mobil dengan sistem dua motor yaitu motor berada pada posisi kanan dan kiri roda belakang dengan sistem in-wheel atau motor BLDC tanpa transmisi yang ditunjukkan pada Gambar 4. Motor BLDC yang digunakan mempunyai daya 800 watt dengan tegangan baterai 48 volt. Dari Persamaan 3 dapat diketahui tegangan yang di dapat saat motor BLDC bekerja serta Persamaan 4 memperlihatkan bentuk Energi yang dikeluarkan oleh motor BLDC (Yin, dkk, 2017).

$$
\begin{gathered}
V a=R_{s} i_{a}+L_{s} i_{a}+E_{a} \\
E a=K_{e} n \phi
\end{gathered}
$$

Pada perancangan sistem kendaraan listrik ini lebih mengutamakan efisiensi energi. Desain kendaraan dibuat seminimal mungkin agar energi yang dikeluarkan tidak terlalu membebani kerja dari motor BLDC. Dari Persamaan 4 Ea merupakan energi yang dihasilkan untuk menggerakkan motor BLDC setara dengan konstanta desain motor BLDC, sehingga beban yang ada harus sesuai dengan daya motor. Untuk menghasilkan putaran pada motor BLDC dibutuhkan tegangan yang dikelurkan Va adalah hasil dari energi Ea ditambah resistasi motor atau Rs kemudian ditambahkan panjang lilitan pada motor yang disimbolkan Ls yang dialiri oleh arus pada sumber tegangan baterai atau $\mathrm{i}_{\mathrm{a}}$. 


\subsection{Rancangan Sistem Elektronik Diferensial Kendaraan Listrik}

Pada perancangan sistem elektronik diferensial kendaraan listrik merupakan suatu pengontrolan kecepatan putar motor BLDC. Sistem kemudi ditambahkan sensor sudut untuk menentukan input kecepatan sesuai perintah dari mikrokontroler.

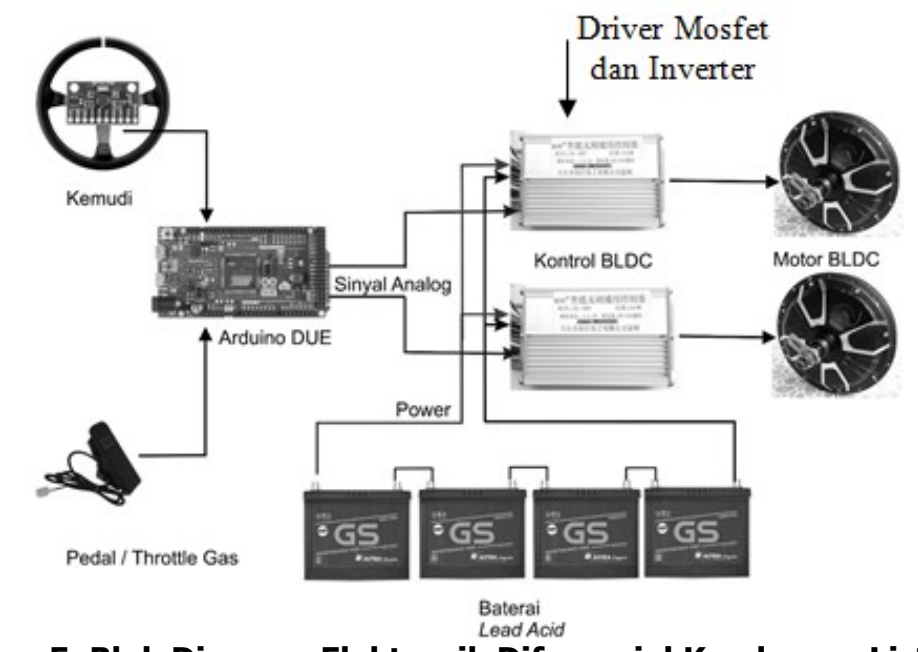

Gambar 5. Blok Diagram Elektronik Diferensial Kendaraan Listrik

Pada perancangan skematik terdapat dua bagian, bagian pertama adalah design dari driver mosfet dan bagian kedua adalah design dari port-port arduino yang menghubungkan dengan rangkaian driver mosfet. Pada perancangann driver mosfet terdapat dua bagian yaitu highside dan low-side. Kedua bagian ini masing-masing mempunyai fungsi untuk proses swithing untuk mendrive mosfet agar menghasilkan gerak memutar pada motor BLDC yang akan dikendalikan kecepatan putarnya. Pada rangkaian driver mosfet terdapat tiga transistor yaitu tipe BC 547 yang sangat sesuai untuk tipe switching dengan tegangan vcc sampai 50 volt pada data sheet. Pada transistor pertama mempunyai fungsi sebagai saklar atau switching. Proses switching melalui input PWM dari mikrokontroler arduino akan dikuatkan oleh transistor kedua. Jika pada proses mendrive mosfet tidak ada penguatan arus maka tegangan pada kaki gate mosfet akan mengalami drop tegangan.

\subsection{Rancangan Kontroler ANN (Artificial Neural Network)}

Pada identifikasi plant dengan ANN ini digunakan untuk menentukan plant yang akan digunakan. Identifikasi plant dibawah ini terdapat satu output yaitu PWM. Identifikasi yang diterapkan disini menggunakan identifikasi model refrence. Berikut ini model dari plant ANN.

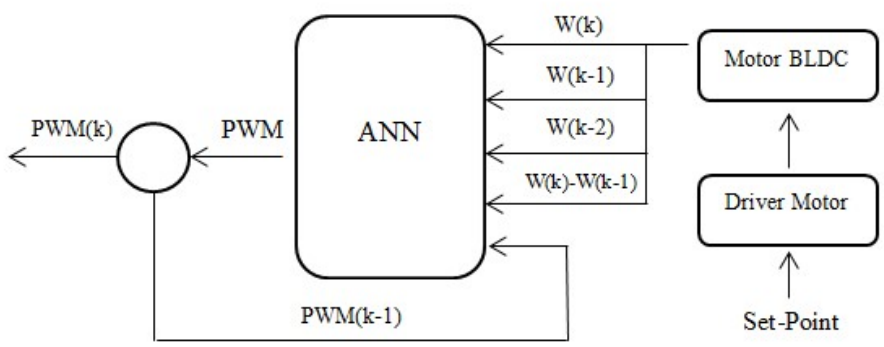

Gambar 6. Blok Diagram ANN (Artificial Neural Network) 
Pada Gambar 6 merupakan model plant dari ANN, model plant ini diterapkan pada software Matlab dengan menggunakan source code yang telah dibuat dan dirancang. Model plant ANN diatas dimana input berupa data rpm dan output berupa data setpoint. Dari input rpm ini nantinya terdapat delay seperti pada Gambar diatas dengan software Matlab sesuai source code yang dibuat. Model plant ini merupakan identifikasi awal yang nantinya akan dijadikan kontrol dari ANN.

Pada tahap ini merupakan perancangan kendali ANN yang akan dibuat. Dari perancangan kontroler ini terdiri dari beberapa langkah yang akan dilakukan dalam perancangan ini. Terdiri dari beberapa blok-blok untuk mendapatkan kontrol ANN. Langkah awal yaitu menentukan identifikasi plant dengan ANN, kemudian akan dilakukan perancangan kendali dengan ANN kontroler dengan kendali adaptif model reference (model acuan) Berikut ini rancangan kendali dengan ANN untuk model MRAC (model reference adaptif control) (Kong, dkk, 2008).

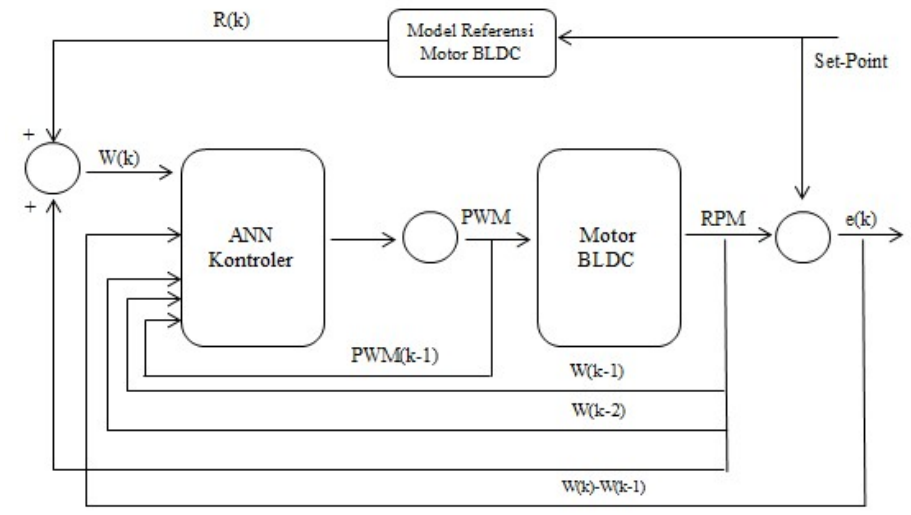

Gambar 7. Sistem Kontrol Elektronik Diferensial Kendaraan Listrik

Dari Gambar 7 perancangan sistem kendali kecepatan motor dengan ANN diatas terdapat beberapa blok sistem. Blok dari plant motor ini data input berupa setpoint atau PWM dan output berupa RPM. Dimana dari hasil plant motor ini yang akan dijadikan identifikasi dari ANN kontroler tetapi untuk output dari plant motor ini nantinya akan dijadikan sebagai input pada ANN kontroler dan output dari ANN kontroler ini berupa PWM motor. Jadi input dari ANN kontroler berupa kecepatan dalam satuan RPM dan sudut kemudi serta output berupa PWM motor. Untuk mendapatkan nilai arus dan kecepatan saat pengujian kendaraan listrik dipakai suatu sensor sebagai parameter untuk di proses dalam sistem ANN ( artificial Neural Network ). Untuk sensor Kecepatan digunakan untuk mendeteksi kecepatan kendaraan listrik yang dipasang pada bagian roda kendaraan yang telah terkalibrasi. Sedangkan untuk sensor sudut dipasang pada kemudi kendaraan. Untuk output dari mikrokontroler berupa nilai PWM yang berubah-ubah yang akan diteruskan ke dalam rangkaian driver mosfet. Nilai PWM semakin besar maka kecepatan putaran motor BLDC pada motor penggerak kanan dan motor penggerak bagian kiri akan bertambah dan begitu juga sebaliknya. Pengaturan kecepatan kendaraan dilakukan melalui trottle atau pedal gas yang dipasang pada bagian kaki pengemudi seperti pada kendaraan pada umumnya. 


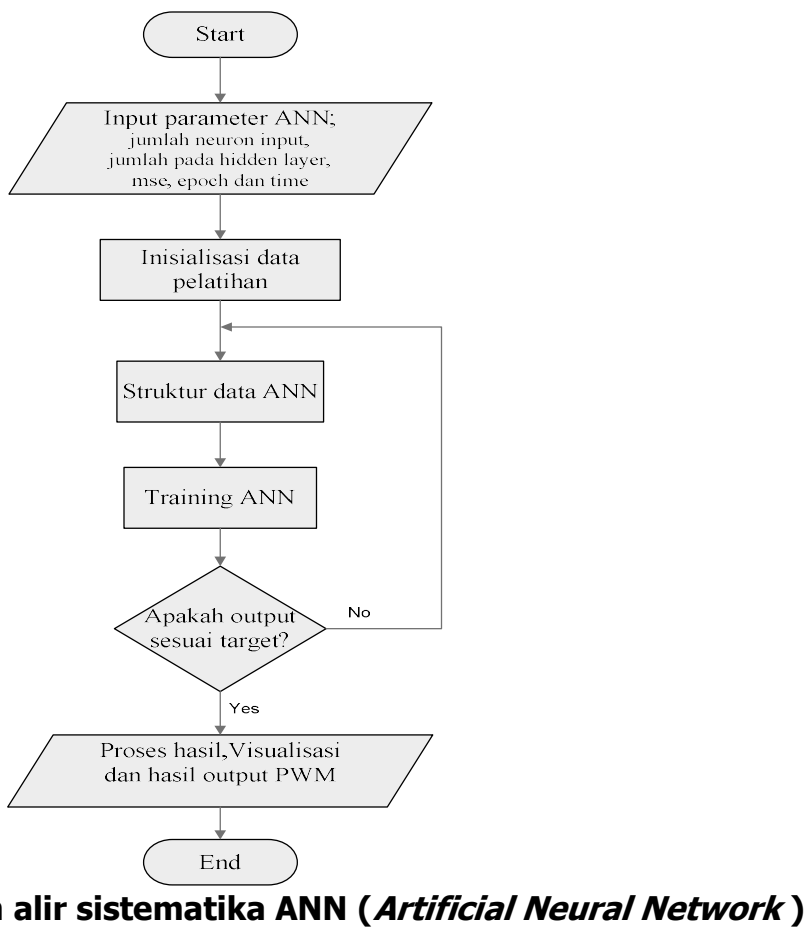

\section{HASIL DAN PEMBAHASAN}

\subsection{Pengujian dan Training Data ANN (Artificial Neural Network)}

Pada proses pengujian ini sebelum melakukan training terlebih dahulu mengambil data secara statis untuk dijadikan data training pada Artificial Neural Network matlab. Pada identifikasi kontrol ANN ini input didapatkan dari pengambilan data statis seperti pada data motor, tetapi untuk input dari training ANN ini berupa data RPM dan output berupa PWM. Sebelum melakukan training data input dan output ini akan dinormalisasi sehingga bisa terstruktur. Input pada training sebanyak lima dan satu output, dimana input ini nantinya di delay. Delay ini secara dilakukan pada software Matlab dengan menggunakan source code atau script pada Matlab sehingga otomatis Matlab akan memproses data dan akan menghasilkan bobot dan bias. Pada data motor ini didapatkan dari hasil pengujian statis dari kontrol motor BLDC pada mobil listrik, dimana pengujian statis ini merupakan pengujian yang dilakukan tanpa ada beban. Dari hasil pengujian ini didapatkan beberapa data dengan variasi nilai ADC 0-255 dengan duty cycle 0-100\%.

Tabel 1. Jumlah Hidden layer, Regression dan MSE

\begin{tabular}{|c|c|c|c|c|c|}
\hline \multirow{2}{*}{ No. } & \multirow{2}{*}{$\begin{array}{c}\text { Hidden } \\
\text { layer Unit }\end{array}$} & \multicolumn{2}{|c|}{ Training } & \multicolumn{2}{c|}{ Testing } \\
\cline { 3 - 6 } & Regression & MSE & Regression & MSE \\
\hline 1 & 5 & 0.99976 & 21.5788 & 0.98817 & 383.9721 \\
2 & 10 & 0.99973 & 23.1907 & 0.98374 & 524.4481 \\
3 & 15 & 0.99973 & 23.7746 & 0.98569 & 462.1304 \\
4 & 20 & 0.99974 & 22.8169 & 0.98240 & 569.3454 \\
5 & 25 & 0.99971 & 25.5995 & 0.98947 & 339.0761 \\
6 & 30 & 0.99977 & 20.8144 & 0.98970 & 331.7477 \\
\hline
\end{tabular}


Pada proses training ini dilakukan dengan beberapa kali training dengan hidden layer yang berbeda-beda untuk mengetahui hasil nilai yang baik. Untuk mengetahui hasil training yang baik ini diperoleh dari nilai regression dan nilai MSE yang muncul setelah proses training selesai. Berikut ini Tabel 1 regression dan MSE hasil training dan testing. Hasil dari training dan testing akan di dapatkan suatu persamaan yang akan di inputkan kedalam algoritma pengendalian elektronik diferensial kontroln motor BLDC. Dalam proses training ini akan mampu memberikan hasil efisiensi energi pada kendaraan listrik yang semakin meningkat saat dilakukan pengujian atau percobaan.
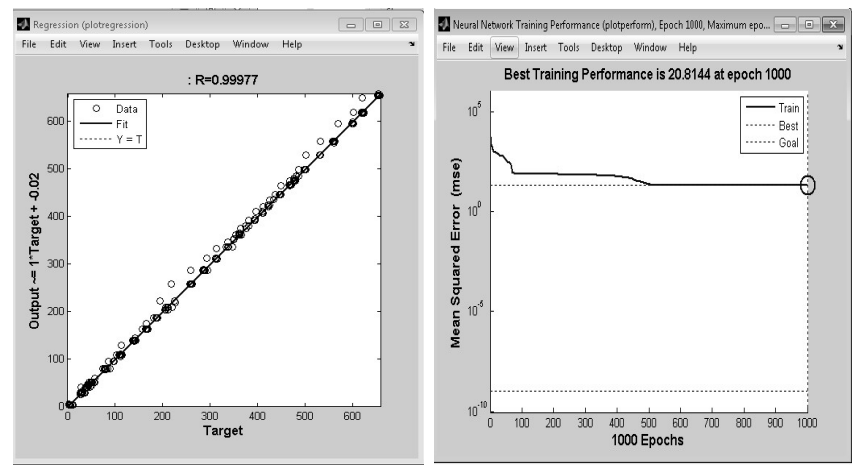

\section{Gambar 9. Regression dan MSE Training}

Pada Gambar 9 proses training dilakukan secara offline dengan literasi sampai epoch ke 1000. Dari hasil training MSE yang tercapai adalah 20.8144. MSE akan muncul saat training secara offline sudah selesai pada literasi yang sudah ditentukan. Pada proses training data akan diolah kemudian akan disesuaikan antara input berupa arus dan sudut kemudi dengan output berupa pengaturan kecepatan putaran motor BLDC diperoleh koefisien korelasi (R) sebesar 0,99977. Hidden Layer yang digunakan sebesar 30 untuk hasil terbaik bernilai 1.

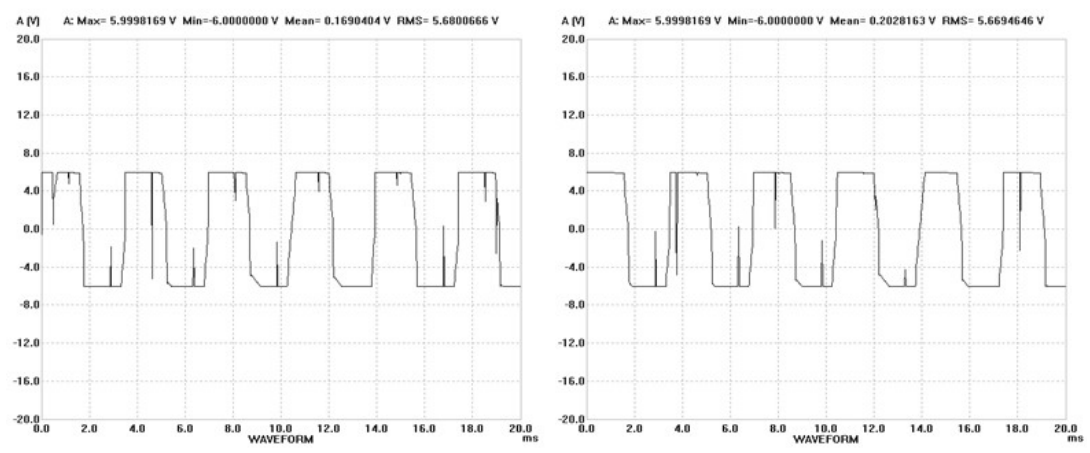

Gambar 10. Sinyal Respon Rangakain Elektronik Differensial

Pada pengujian respon sistem bertujuan untuk mengetahui bagaimana respon kecepatan dalam RPM terhadap nilai set-point yang diberikan oleh mikrokontroler dapat dilihat pada Gambar 10. Pengujian ini dilakukan tanpa beban atau motor berputar bebas dengan perubahan nilai set-point yang tidak terlalu signifikan. Jika kecepatan motor dalam satuan RPM dapat mendekati nilai set-point maka efisiensi pada kontrol yang telah diracang dapat meningkat. Pengujian tanpa kontrol mendapatkan hasil yang sesuai yaitu mengalami over shoot kenaikan RPM yang tidak terkontrol. 


\subsection{Pengujian Percepatan Pada Kendaraan Listrik}

Pengujian Percepatan adalah suatu bentuk pengujian akselerasi ketangguhan sistem kendaraan listrik saat digunakan di jalan dengan pengemudian di lintasan lurus.

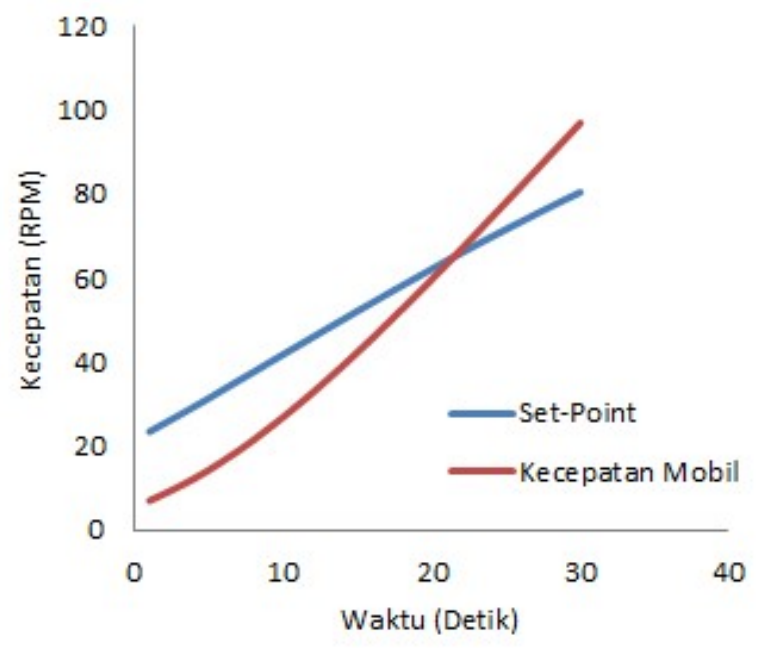

(a)

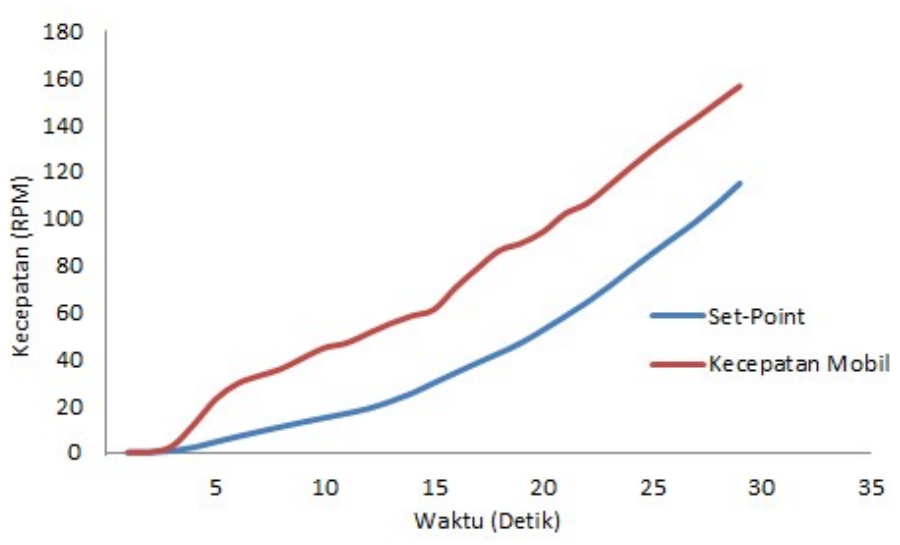

(b)

\section{Gambar 11. Grafik (a) Pengujian Percepatan Kendaraan Listrik tanpa kontrol ANN Grafik (b) Pengujian Percepatan Kendaraan menggunakan kontrol ANN}

Pada Gambar 11 adalah grafik antara nilai set-point terhadap kecepatan dalam RPM. Pada Gambar 11(a) merupakan pengujian percepatan kendaraan listrik tanpa kontrol ANN dan Gambar 11(b) merupakan pengujian percepatan kendaraan kendaraan menggunakan kontrol ANN. Pengujian percepatan dilakukan dengan menjalankan sistem pada jarak 200 meter. Pada pengujian percepatan ini lebih menekankan pada kenaikan arus. Nilai set-point yang diberikan tidak dapat di imbangi dengan kenaikan nilai RPM yang diinginkan karena ada pengaruh dari kenaikan arus pada kontrol motor BLDC. 


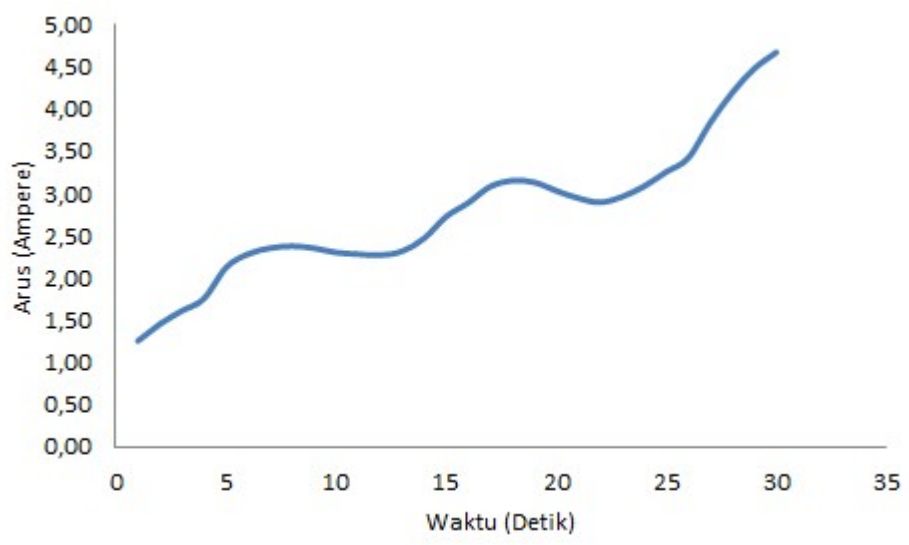

(a)

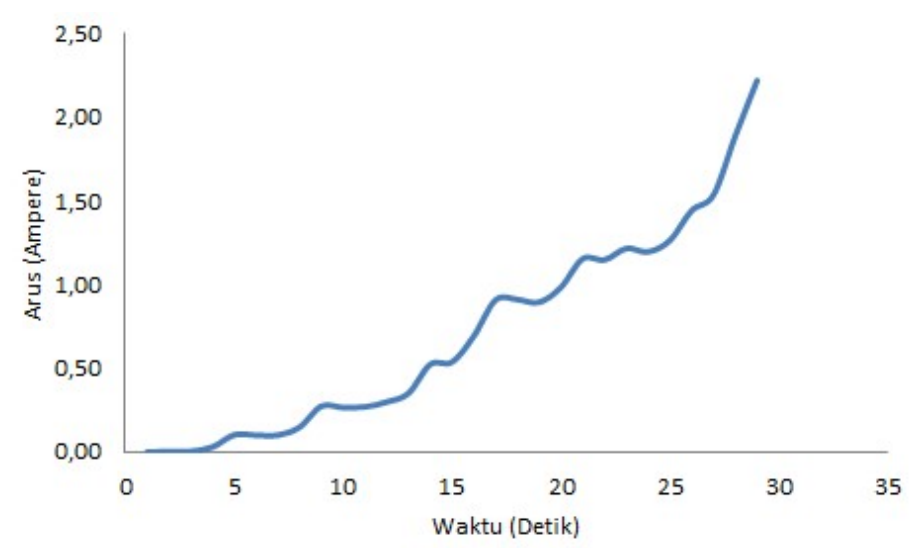

(b)

\section{Gambar 12. Grafik (a) Pengujian Arus pada Percepatan Kendaraan Listrik tanpa Kontrol ANN, Grafik (b) Pengujian Arus pada Percepatan Kendaraan Listrik Menggunakan Kontrol ANN}

Pada Gambar 12 adalah grafik kenaikan arus pada pengujian percepatan. Gambar 12 bagian (a) adalah pengujian arus kendaraan tanpa kontrol ANN sedangkan Gambar 12 bagian (b) adalah pengujian arus pada kendaraan menggunakan kontrol ANN. Nilai arus pada percobaan percepatan semakin meningkat dikarenakan kenaikan dari kecepatan dalam RPM dalam sesaat. Perubahan nilai set-point yang cepat dalam pengujian percepatan akan memberikan pengaruh perubahan yang drastis pada nilai kecepatan sehingga arus akan meningkat dengan cepat. Hasil pengujian tanpa kontrol ANN diperoleh arus rata-rata sebesar 1,34 ampere. Kemudian dari pengujian menggunakan kontron ANN didapatkan arus ratarata sebesar 1,05 ampere. Arus pada awal sistem bekerja naik dengan pelan karena kontrol neural network menekan kenaikan PWM yang cepat akibat kontrol arus pada sistem neural network.

\subsection{Pengujian Efisiensi Energi Pada Kendaraan Listrik}

Dalam pengujian efisiensi energi pada kendaraan listrik merupakan suatu bentuk analisa energi saat kendaraan listrik digunakan secara langsung di lintasan atau di jalan raya. 


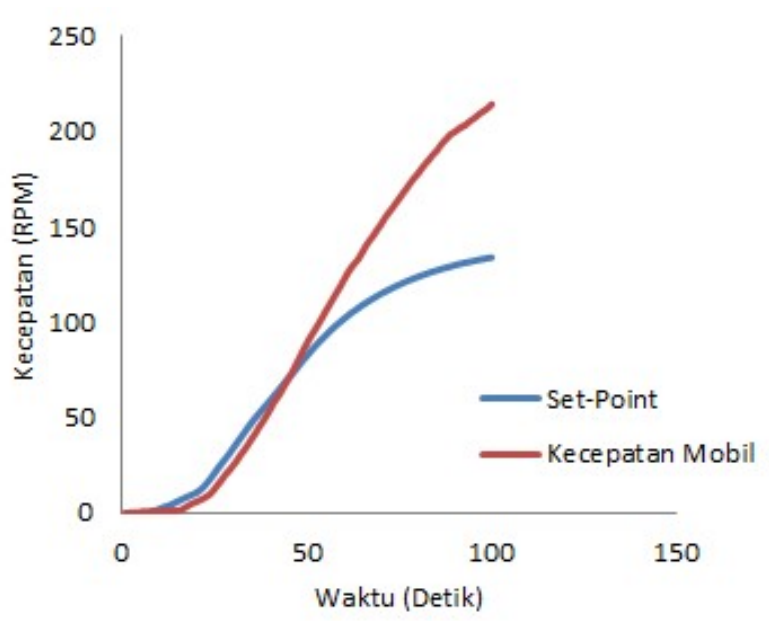

(a)

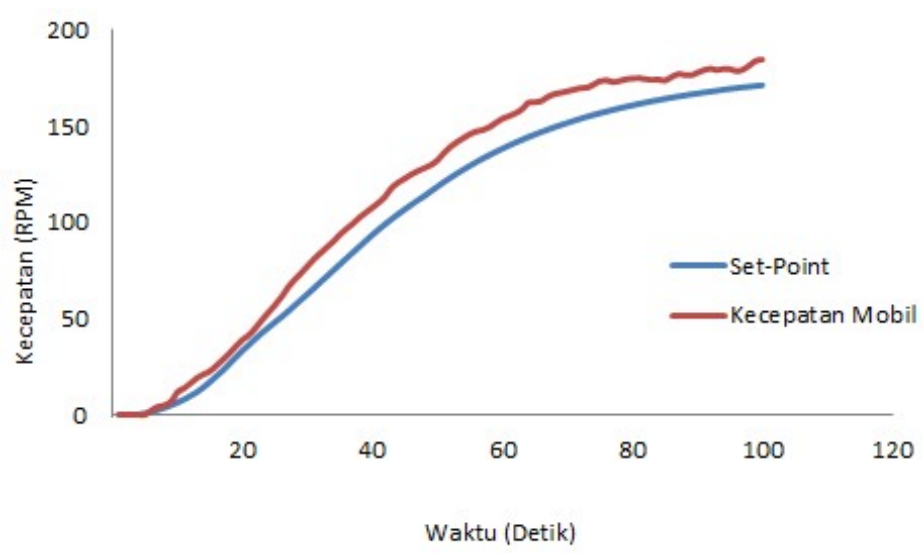

(b)

Gambar 13. (a) Grafik Pengujian Efisiensi Energi Kendaraan Listrik tanpa Kontrol ANN

(b) Grafik Pengujian Efisiensi Energi Kendaraan Listrik Menggunakan Kontrol ANN

Pada Gambar 13 bagian (a) merupakan pengujian efisiensi energi kendaraan litrik tanpa kontrol ANN, sedangkan Gambar 13 bagian (b) dapat dilihat grafik dari pengujian efisensi pada mode close-loop atau menggunakan kontrol ANN dengan nilai daya yang tidak stabil pada satuan waktu. Nilai daya rata-rata yang diperoleh adalah 101 watt. Kemudian pada alat ukur energi meter energi yang turukur untuk menyelesaikan lintasan 3,3 km adalah 18,4 kwh. Untuk persamaan efisiensi energi dapat dilihat pada Persamaan 5 berikut ini :

$$
\text { Efisiensi Energi }=(\text { Panjang Lintasan }(K M) \times 1000) / \text { Energi }(W H)
$$


Tabel 2. Perbandingan Pengujian kontrol ANN

\begin{tabular}{|c|c|c|c|c|}
\hline \multirow{2}{*}{ No. } & \multirow{2}{*}{ Kontrol } & \multicolumn{3}{|c|}{ Pengujian } \\
\cline { 3 - 5 } & $\begin{array}{c}\text { Arus Pengujian } \\
\text { Percepatan }\end{array}$ & Efisiensi Energi & $\begin{array}{c}\text { Energi yang } \\
\text { dikeluarkan }\end{array}$ \\
\hline 1 & Tanpa Kontrol ANN & 1,34 ampere & $1 \mathrm{KWH}=171,45 \mathrm{KM}$ & 110 watt \\
\hline 2 & $\begin{array}{c}\text { Menggunakan Kontrol } \\
\text { ANN }\end{array}$ & 1,05 ampere & $1 \mathrm{KWH}=179,34 \mathrm{KM}$ & 101 watt \\
\hline
\end{tabular}

Pada Tabel 2 dapat dilihat perbandingan penggunaan kontrol ANN dengan pengujian tanpa kontrol ANN. Dari pengujian efisiensi energi tanpa kontrol ANN di dapatkan perpindahan energi yaitu $1 \mathrm{KWH}$ energi pada baterai dapat menggerakkan kendaraan sejauh 171,45 KM atau $171,45 \mathrm{KM} / \mathrm{KWH}$ yang dapat dilihat pada Gambar 13 bagian (a). Kemudian untuk hasil pengujian efisiensi energi menggunakan kontrol ANN didapatkan perpindahan energi $1 \mathrm{KWH}$ energi pada baterai dpat menggerakkan kendaraan sejauh 179,34 KM atau 179,34 km/kwh dapat dilihat pada Gambar 13 bagian (b). Dari hasil perbandingan antara tanpa kontrol $A N N$ (Artificial Neural Network) dengan kontrol menggunakan ANN (Artificial Neural Network) dapat mempengaruhi efisiensi energi yang dikeluarkan dengan memperhatikan kenaikan arus yang bisa diolah menjadi suatu kontrol untuk kendaraan listrik.

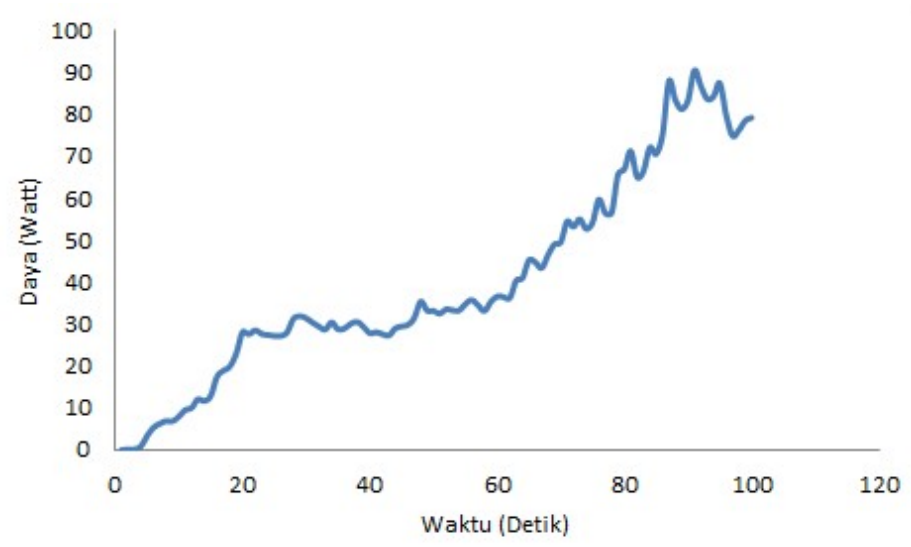

(a)

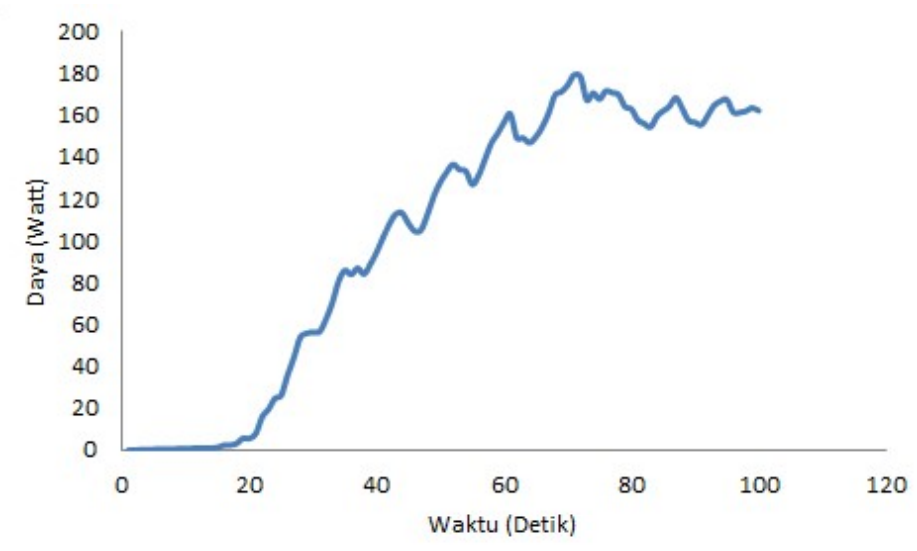

(b)

Gambar 14. (a) Grafik Daya Pengujian Efisiensi Kendaraan Listrik tanpa Kontrol ANN (b) Grafik Daya Pengujian Efisiensi Kendaraan Listrik Menggunakan Kontrol ANN 
Pada Gambar 14 adalah grafik daya pada pengujian efisiensi. Daya rata-rata dalam pengujian sistem adalah 110 watt jika tanpa kontrol ANN yang ditunjukkan pada Gambar 14 bagian (a). Sedangkan pada Gambar 14 bagian (b) adalah grafik pengujian Daya motor menggunakan kontrol ANN ddapat nilai sebesar 101 watt. Dalam grafik nilai daya berubahubah karena kondisi dari pengujian antara lain lintasan yang naik pada tanjakan serta pada waktu sistem berbelok. Jika arus meningkat dalam sesaat maka kenaikan daya akan terjadi.

\section{KESIMPULAN}

Berdasarkan hasil penelitian yang telah dilakukan diperoleh beberapa kesimpulan yaitu dalam pengujian percepatan dengan menempuh jarak 200 meter dapat diperoleh nilai arus rata-rata sebesar 1,05 ampere. Kemudian untuk pengujian efisiensi dengan menempuh jarak 3,3 km dengan waktu 10 menit dapat diperoleh kecepatan rata-rata sebesar 198,27 RPM dengan daya rata-rata sebesar 101 watt dengan konsumsi energi pada alat ukur energi meter sebesar 179,34 km/kwh.

\section{UCAPAN TERIMA KASIH}

Terima Kasih Kepada UKM Mobil Listrik TITEN Universitas Jember sebagai tempat dalam belajar dan tempat laboratorium dalam belajar seputar kendaraan listrik.

\section{DAFTAR RUJUKAN}

Al-Fiky, H. T., Asfoor, M. S., Mostafa I. Yacoub, \& Sharaf, A. H. (2019). Speed Control Modeling for In-Wheel Permanent Magnet Brushless DC Motors for Electric Vehicles. 2019 24th International Conference on Methods and Models in Automation and Robotics, MMAR 2019, (pp. 438-43). https://doi.org/10.1109/MMAR.2019.8864664.

Daya, F. J. L., Sanjeevikumar, P., Blaabjerg, F., Wheeler, P. W., Ojo, J. O., \& Ertas, A. H. (2016). Analysis of Wavelet Controller for Robustness in Electronic Differential of Electric Vehicles: An Investigation and Numerical Developments. Electric Power $\begin{array}{llll}\text { Components } \quad \text { and } & \text { 44(7), }\end{array}$ https://doi.org/10.1080/15325008.2015.1131771.

Dehong, C., Qichen, G., Peng, X., Huadong, L., Hao, Z., \& Kai, T. (2017). The Research about Self-Balancing Mobile Platform Based on Differential Wheel. Proceedings of the 29th Chinese Control and Decision Conference, CCDC 2017, (pp. 6072-77). https://doi.org/10.1109/CCDC.2017.7978261.

Gago-Calderón, A., Clavero-Ordóñez, L., Andrés-Díaz, J. R., \& Fernández-Ramos, J. (2019). Hardware Architecture and Configuration Parameters of a Low Weight Electronic Differential for Light Electric Vehicles with Two Independent Wheel Drive to Minimize Slippage. World Electric Vehicle Journal, 102). https://doi.org/10.3390/wevj10020023. 
Jigang, H., Hui, F., \& Jie, W. (2019). A PI Controller Optimized with Modified Differential Evolution Algorithm for Speed Control of BLDC Motor. Automatika, 60(2), 135-48. https://doi.org/10.1080/00051144.2019.1596014.

Kivanc, O. C., \& Ustun, O. (2019). Dynamic Control of Electronic Differential in the Field Weakening Region. International Journal of Electronics, 106 (10), 1583-1601. https://doi.org/10.1080/00207217.2019.1600742.

Kong, X., Cheng, M., \& Shu, Y. (2008). Extreme Learning Machine Based Phase Angle Control for Stator-Doubly-Fed Doubly Salient Motor for Electric Vehicles. 2008 IEEE Vehicle Power and Propulsion Conference, VPPC 2008, (pp. 3-7). https://doi.org/10.1109/VPPC.2008.4677510.

Prasetyo, H. F., Rohman, A. S., Hariadi, F. I., \& Hindersah, H. (2017). Controls of BLDC Motors in Electric Vehicle Testing Simulator. Proceedings of the 2016 6th International Conference on System Engineering and Technology, ICSET 2016, (pp. 173-78). https://doi.org/10.1109/FIT.2016.7857560.

Setiawan, J. D., Haryanto, I., Munadi, \& Sutanto, I. (2019). Modeling and Analysis of Lateral Control System on Electronic Differential for 2-Independent-Wheel Drive Electric Urban Bus. Proceeding - 2018 5th International Conference on Electric Vehicular Technology, ICEVT 2018, (pp. 36-40). https://doi.org/10.1109/ICEVT.2018.8628428.

Yin, D., Shan, D., \& Hu, J. S. (2017). A Study on the Control Performance of Electronic Differential System for Four-Wheel Drive Electric Vehicles. Applied Sciences (Switzerland), ス1). https://doi.org/10.3390/app7010074. 